the agency to provide Congress with annual reports on how it is spending its space station money, and how the Russians are spending theirs.

"Dan Goldin [the administrator of NASA] has made some pretty grandiose promises which are going to be very difficult to live up to," says Roemer. "I'm going to hold him to these promises." $\mathrm{He}$ is also working with George Brown(Democrat, California), chairman of the House Science, Space and Technology Committee, on a provision in the bill that would cap annual station spending at its current level of \$2.1 billion.

Describing last month's vote in favour of the space station as "a temporary setback", Roemer concedes he made a tactical mistake in proposing that the station money go back into NASA, rather than making it a straight spending cut. "But I don't think it was one of the major reasons we lost," he says. "Probably in future, with the budget difficulties we face, a straight cut will be the way to go."

He does not see the 1995 vote as taking the project to the point where it cannot be cancelled. "We're talking about spending another $\$ 50-\$ 55$ billion on this," says Roemer. Very important projects such as Advanced X-Ray Astrophysics Facility, Cassini and Mars Surveyor may in fact be cancelled because of the space station. But for this year, as Mikulski's budget confirmed, these projects are safe.

Colin Macilwain

\section{Warheads give boost to nuclear fuels}

London. Uranium produced from the dismantling of nuclear warheads could provide up to 15 per cent of the world's supply of uranium fuel within ten years, according to forecasts made on behalf of the international uranium industry.

In a report published last week, the Uranium Institute, which is based in London, predicts that highly enriched uranium derived from obsolete nuclear weapons, and converted for use in commercial nuclear power plants, could be supplying between 5 and 15 per cent of world supplies over the next decade.

According to the institute, this supply will go some way to meeting the sharp rise in demand for uranium that it believes will take place in response to increasing global energy demands.

Under an arrangement reached with Russia in 1993, the United States has agreed to buy 500 tonnes of highly-enriched uranium resulting from the destruction of weapons. The destruction is itself one result of the START II treaty, signed by the then US president, George Bush, and his Russian counterpart, Boris Yeltsin, in 1993, in which both countries agreed to cut nuclear weapons by two-thirds.

Maggie Verrall

\title{
Locals seek strict controls over UCSF expansion plans
}

San Francisco. Plans by the space-starved University of California at San Francisco (UCSF) to build a new medical research complex on part of a former Army base in the city may have to meet stringent conditions laid down by local residents if they are to proceed with public support.

An alliance of nine neighbourhood groups is recommending several conditions to be attached to the UCSF plans for the 60 -acre Letterman complex at the San Francisco Presidio site, which is due to become a national park this autumn. The conditions include a height limit on new buildings, measures to mitigate traffic, a promise not to expand beyond the federal property, ventilation systems and the proper disposal of hazardous materials - and an agreement to limit animals used in research to small rodents, such as mice and rats.

The site already houses a research centre and a hospital building. UCSF's planned medical research complex could cost between $\$ 150$ million and $\$ 200$ million for new construction and renovation, and would be used by $2,500-3,500$ employees.

Research topics under consideration include population dynamics, epidemiology, microbial diseases, human genetics, structural biology, cell biology and other basic medical sciences. The university also plans to use the site for public education projects on biomedical research.

UCSF, which employs 15,000 people on four major sites, several smaller ones and in two affiliate hospitals, has had a tempestuous relationship with local residents in the recent past. Attempts to build research laboratories in a former insurance building in the prosperous Laurel Heights neighbourhood, for example, led to eight years of legal wrangling.

Now, as the university begins negotiations over potential leasing arrangements for the Presidio site, campus officials are determined not to repeat their mistakes. "We have learned from previous errors,"

says the vice chancellor, Bruce Spaulding, adding that the university has decided to involve local community groups in the planning process at a very early stage.

The university has recruited a group of 38 community advisers to help it to deal with local issues in developing plans for several potential sites for expansion. Many were selected because of their previous involvement in struggles with the university.

John Corsiglia, a member of the group and a neighbourhood activist who opposed the Laurel Heights expansion, calls the advisers "the best thing the university ever did". He says that since the committee was formed three years ago, the university had both listened and responded to those affected by its institutions.

In a plan to build a utility plant on its main campus earlier this year, for example, UCSF spent an additional $\$ 4$ million on soundproofing to meet neighbourhood concern about noise. "The university's image used to be 'we can do as we damn please' and it was true," says Corsiglia. "That image is beginning to change."

In a bid to overcome hostility to the university's plans, UCSF officials have also held almost 20 workshops with neighbourhood associations and the general public to discuss potential locations. One suburb asked for help with local science education programmes, while an inner city neighbourhood sought assurances that local workers would get preference for construction jobs.

A primary concern behind all this has been the university's potential for unchecked growth through its use of state authority. Redmond Kernan, co-chair of the alliance, says many neighbours are concerned "because UCSF has a reputation for not being very easy to deal with". But he says the site might be a good one because the school would be kept in check by federal authority. "San Francisco needs to keep UCSF,"Kernan says.

Sally Lehrman

\section{Italy backs new national physics institute}

Rome. The Italian government has approved a decision to transform the Interuniversity Consortium for the Physics of Matter, a body which links 36 Italian universities, into a National Institute for the Physics of Matter.

The consortium was set up in 1987 and is based in Genoa. It is responsible for a number of broad-ranging activities funded by both the Italian government and the EC, including programmes aimed at transferring technology to industry and at boosting the technology base in the poorer regions of Italy.

The new institute, which will take over these responsibilities, will work closely with universities in fields such as condensed matter, quantum electronics, atomics molecular and plasma physics, computational physics, and biophysics.

It will have direct contacts with the European Synchrotron Radiation Facility in Grenoble and a domestic facility in Trieste. A key goal will be to promote the participation of Italian physicists in European research programmes. 